\title{
Characterization of a Corn Fiber Protein Film Containing Green Tea Extract
}

\author{
Hyun-Ju Yang $\cdot$ Ji-Hyun Lee $\cdot$ Ji-Hyeon Lee $\cdot$ Kyung Bin Song*
}

\section{녹차 추출물을 함유한 옥피 단백질 필름의 특성}

양현주 · 이지현 · 이지현 · 송경빈*

Received: 12 January 2015 / Accepted: 11 March 2015 / Published Online: 30 June 2015

(C) The Korean Society for Applied Biological Chemistry 2015

\begin{abstract}
Corn fiber protein (CFP) was extracted from corn wetmilling by-product, corn fiber. CFP films containing various plasticizers and cross-linking agents were prepared and their mechanical properties were determined. Among the plasticizers and cross-linking agents used in this study, the CFP film containing $2 \mathrm{~g}$ fructose and $0.03 \%$ cinnamaldehyde had the most appropriate physical property. In addition, the CFP films containing green tea extract (GTE) were prepared by incorporating different amounts $(0,0.5,1.0,1.5 \%)$ of GTE into the film-forming solution. Tensile strength, film solubility, and opacity of the CFP films increased with the addition of GTE, whereas elongation and water vapor permeability of the CFP/GTE films decreased compared to those of the control. The antioxidant activity of the CFP/GTE film was determined in terms of 2,2-diphenyl-1-picrylhydrazyl radical scavenging activity. As a result, antioxidant activity of the films increased with increasing GTE concentration. Furthermore, antimicrobial activity against Escherichia coli O157:H7, Listeria monocytogenes, and Staphylococcus aureus increased with increasing GTE concentration. These results indicate that the incorporation of GTE could enhance antioxidant and antimicrobial activities of the CFP films.
\end{abstract}

H.-J. Yang $\cdot$ J.-H. Lee $\cdot$ J.-H. Lee $\cdot$ K. B. Song

Department of Food Science and Technology, Chungnam National University, Daejeon 305-764, Republic of Korea

*Corresponding author (K. B. Song: kbsong@cnu.ac.kr)

This is an Open Access article distributed under the terms of the Creative Commons Attribution Non-Commercial License (http://creativecommons. org/licenses/by-nc/3.0/) which permits unrestricted non-commercial use, distribution, and reproduction in any medium, provided the original work is properly cited.
Keywords antimicrobial property $\cdot$ corn fiber $\cdot$ green tea extract - protein film

\section{서 론}

식품의 저장, 유통 중 품질을 유지시키고 외부 환경에 대한 식 품의 오염을 막는 역할을 하는 식품 포장재의 대부분은 플라스 틱으로 생분해가 되지 않아 환경오염의 원인이 되기에 $(\mathrm{Lim}$ 등, 2010), 최근 생분해가 가능한 가식성 필름에 대한 연구가 활발 히 진행 되고 있다(Hong 등, 2009). 가식성 필름은 다당류, 단 백질, 지방과 같은 원료가 단일 또는 복합되어 제조되는데(Shin 등, 2013), 일반적으로 플라스틱 필름에 비해 충격에 대한 저항 이 약해 쉽게 부서지고, 열에 대한 저항성 등이 약하다. 이를 개선하기 위해 필름의 신장성과 유연성을 증가 시켜주는 가소 제와 인장강도, 흡습에 대한 저항성 등을 증가시켜주는 가교제 를 첨가해야 하는데, 가식성 필름의 원료와 가소제, 가교제에 따라 성질이 다르므로 최적의 물성을 갖는 가소제, 가교제의 선 정이 중요하다(Galietta 등, 1998; Cao 등, 2007; Lim 등, 2009; Song 등, 2013).

옥피(corn fiber)는 옥수수 전분을 제조하는 공정의 부산물로 써(Gáspár 등, 2007), 옥수수를 습식 분쇄 하여 surfur dioxide 로 전처리 한 후 물에 녹지 않고 부유되는 물질들로 섬유질 $52.6-73.5 \%$, 전분 $15-20 \%$, 단백질 $10-13 \%$ 등으로 구성되어 있 다(Shukla와 Cheryan, 2000; Rose 등, 2010). 옥피는 연간 4-5 백만 톤이 생산되는데, 대부분 동물사료로만 사용되고 있어서 이를 활용한 고부가가치 식품소재에 관한 연구가 진행되어 왔 다(Wang 등, 2008; Rose 등, 2010). 특히 옥피 가격이 매우 저렴하기 때문에 옥피로부터 추출한 옥피 단백질(corn fiber protein, $\mathrm{CFP}$ )은 가격 경쟁력 측면에서 corn zein 등 기존 가식 성 필름의 단점을 보완할 수 있어서 필름 원료로 사용하기에 
적합하다(Wang 등, 2008).

식품의 저장성을 증대시킬 목적으로 최근에는 천연 항균, 항 산화 물질을 많이 이용하는 추세인데(Lim 등, 2009), 그 중에 서도 녹차 추출물(green tea extract, GTE)은 epicatechin, epicatechin gallate, epigallo-catechin, epigallocatechin gallate와 같은 폴리페놀 성분이 많이 함유되어 있어 천연 항균, 항산화 제로 많이 사용되고 있다(Wu 등, 2013). 또한, GTE를 첨가한 gelatin 필름을 돼지고기 포장에 적용 한 결과 미생물의 생장을 억제하는 항균효과가 있었고(Hong 등, 2009), 잣과 호두에 GTE 를 함유한 단백질 코팅을 하여 저장 중 유지 산패를 억제하는 등 식품 적용에 관한 연구결과가 기존에 보고된 바 있다(Lee 등, 2004).

따라서 본 연구에서는 옥피로부터 수율을 높이기 위한 여러 방법으로 단백질을 추출하여 추출방법을 최적화한 후 얻어진 저 가의 $\mathrm{CFP}$ 에 적합한 가소제와 가교제를 첨가하여 최적의 물성 을 갖는 필름을 제조하고, 천연물질인 $\mathrm{GTE}$ 를 첨가하여 $\mathrm{CFP}$ 필 름의 항산화성, 항균성을 증가시킴으로써, 식품포장재로의 활용 을 도모하고자 하였다.

\section{재료 및 방법}

실험 재료. 본 실험에 사용된 옥피는 삼양제넥스(Korea)에서 제 공받아 사용하였다. Glycerol (GLY), fructose (FRU), sucrose (SUC), sorbitol (SOR), ferulic acid, tannic acid, cinnamaldehyde 는 Sigma-Aldrich Chemical Co. (USA) 제품을 사용하였다. 녹 차 추출물은 대전에 위치한 마트에서 가루녹차를 구입하여 추 출한 후 사용하였다.

옥피 단백질(CFP) 추출. CFP는 옥피로부터 수용성 추출, 알칼 리 처리, 등전점 침전, 유기용매 추출 등으로 획득하였다. 수용 성 추출 방법은 옥피에 10 배 증류수를 첨가하여 $80^{\circ} \mathrm{C}$ 에서 3 시 간 추출 한 뒤 $10,000 \times g$ 에서 30 분간 원심분리(SUPRA22R, Hanil Science Industrial Co., Korea)하여 상층액을 cheese cloth로 여과한 후, 여과된 용액에 $70 \%$ 황산암모늄을 첨가하여 $4^{\circ} \mathrm{C}$ 에서 1 시간 교반하였다. 교반 후 $10,000 \times g$ 에서 30 분간 원심 분리 하여 얻어진 침전물을 염 제거를 위해 투석 $(\mathrm{Mw}$ cut-off $3.5 \mathrm{kDa}$ ) 한 후 동결건조 하였다(Shin 등, 2011). 알칼리 추출 방법은 옥피에 10 배 증류수를 첨가한 뒤 $1 \mathrm{M} \mathrm{NaOH}$ 로 $\mathrm{pH}$ 를 11 로 맞춘 뒤 $80^{\circ} \mathrm{C}$ 에서 3 시간 추출 하였고(Shukla와 Cheryan, 2000), 다음 과정은 수용성 추출 방법과 동일하였다. 등전점 침 전 추출방법은 옥피에 10 배 증류수를 첨가한 뒤 $1 \mathrm{M} \mathrm{NaOH}$ 으 로 $\mathrm{pH}$ 를 11 로 맞춘 뒤 $80^{\circ} \mathrm{C}$ 에서 3 시간 추출 한 후 $10,000 \times g$ 에서 30 분간 원심분리 하여 상층액을 cheese cloth로 여과하였 다. 여과된 용액을 $1 \mathrm{M} \mathrm{HCl}$ 을 이용해 $\mathrm{pH}$ 6.2로 조정하면서 1 시간 교반한 뒤 $10,000 \times g$ 에서 30 분간 원심분리 한 후 얻어진 침전물을 동결건조 하였다(Song 등, 2013). 유기용매 추출 방법 은 옥피에 5 배의 $70 \%$ 에탄올을 첨가해 1 시간 교반한 뒤 $10,000 \times g$ 에서 30 분간 원심분리 하여 상층액을 cheese cloth로 여과 후 감압 농축한 다음 동결건조 하였다(Mchugh 등, 1994). Green tea extract (GTE) 추출. 녹차추출물(GTE)은 가루녹차 $(100 \%$ 녹차 잎 $)$ 를 $80^{\circ} \mathrm{C}$ 의 10 배 증류수를 첨가 해 30 분 교반한 뒤, Whatman (USA) No. 2 filter paper로 여과한 다음 $40^{\circ} \mathrm{C}$ 에서 60 분간 감압 농축한 후 동결건조 하였다(Chiu와 Lai, 2010).
Sodium dodecyl sulfate-polyacrylamide gel electrophoresis (SDS-PAGE). SDS-PAGE는 Laemlli (Laemlli, 1970)의 방법을 이용해 실시하였다. 사용된 separating gel은 $12.5 \%$ acrylamide gel로 증류수 $9.5 \mathrm{~mL}, 30 \%$ acrylamide $12.5 \mathrm{~mL}, 1.5 \mathrm{M}$ Tris (pH 8.8) $7.5 \mathrm{~mL}, 10 \%$ SDS $300 \mu \mathrm{L}, 10 \%$ ammonium persulfate $150 \mu \mathrm{L}, \mathrm{N}, \mathrm{N}, \mathrm{N}$ ',N'-tetramethylethylenediamine (TEMED) $15 \mu \mathrm{L}$ 의 조성으로 제조되었으며, stacking gel은 증류수 $3.4 \mathrm{~mL}, 30 \%$ acrylamide $0.8 \mathrm{~mL}, 1 \mathrm{M}$ Tris (pH 6.8) $0.6 \mathrm{~mL}, 10 \%$ SDS $50 \mu \mathrm{L}, 10 \%$ ammonium persulfate $50 \mu \mathrm{L}$, TEMED $5 \mu \mathrm{L}$ 의 조 성으로 제조하였다. Sample은 단백질에 $5 \mathrm{x}$ sample buffer (1 M Tris- $\mathrm{HCl} \quad 0.6 \mathrm{~mL}, \quad 50 \%$ glycerol $2 \mathrm{~mL}, \quad 10 \%$ SDS $2 \mathrm{~mL}$, dithiothreitol $0.5 \mathrm{~mL}, 1 \%$ bromophenoblue $1 \mathrm{~mL}$, urea $4.8 \mathrm{~g}$, 증류수 $0.9 \mathrm{~mL}$ )를 첨가하여 사용하였고, 전기영동은 $20 \mathrm{~mA}$ 로 분리했으며, Coomassie brillant blue R-250을 사용하여 염색한 다음 탈색시켰다(Shin 등, 2011).

필름형성 용액 및 필름 제조. CFP 필름을 제조하기 위하여, $100 \mathrm{~mL}$ 증류수에 $5 \mathrm{~g} \mathrm{CFP}$ 와 $2 \mathrm{~g} \mathrm{FRU,} \mathrm{다양한} \mathrm{농도의} \mathrm{cinnamaldehyde}$ $(0.01,0.03,0.05 \%)$ 를 첨가한 뒤, 30 분 간 stirring 후 $13,500 \mathrm{rpm}$ 에서 homogenization 하고 5분 간 degassing 하였으며, CFPGTE 필름을 제조하기 위하여 다양한 양의 GTE $(0.5,1.0$, $1.5 \%)$ 를 첨가하였다. 제조된 필름형성 용액을 cheese cloth를 이 용하여 거른 후 Teflon 코팅한 유리판 $(24 \times 30 \mathrm{~cm})$ 에 균일한 양 의 필름용액 $(80 \mathrm{~mL})$ 을 부어 실온에서 24 시간 건조하여 필름을 제조하였다(Lee 등, 2014).

인장 강도 및 신장률. 필름의 인장강도(tensile strenth, $\mathrm{TS}$ )와 신 장률(elongation at break, E)은 ASTM Standard Method D882-91 방법(ASTM, 1993)에 따라 Instron Universal Testing Machine (Model 4484, Instron Co., USA)을 사용하여 측정하 였다. 측정 전 필름은 상대습도가 $50 \%$, 온도가 $25^{\circ} \mathrm{C}$ 로 조절되 는 항온 항습기에서 48 시간 저장하여 수분 함량을 조절 한 다 음, $2.54 \times 10 \mathrm{~cm}$ 의 크기로 절단하여 한 시료 당 7 번 반복 측정 하였다. 초기 grip 간의 거리는 $5 \mathrm{~cm}$, cross head의 속도는 50 $\mathrm{cm} / \mathrm{min}$ 의 조건에서 필름의 $\mathrm{TS}$ 는 필름이 절단될 때까지 작용한 힘을 필름의 초기 단면적으로 나누어 계산하였고, 필름의 $\mathrm{E}$ 는 필름이 절단될 때까지 움직인 거리를 초기 grip간의 거리에 대 한 백분율을 이용해 나타내었다.

필름의 수분 측정. 필름의 수분투과도(water vapor permeability, WVP)는 ASTM Standard Method E96-85 방법(ASTM, 1983) 에 따라 polymethylacrylate cup을 사용하여 필름을 상대습도 $50 \%$, 온도 $25^{\circ} \mathrm{C}$ 로 조절되는 항온 항습기에 보관하면서 필름을 통해 수분이 흡습 함에 따른 cup의 무게 감소를 매 시간 마다 측정하였다. 필름의 수분 용해도(water solubility, WS)는 $\mathrm{AOAC}$ 방법(AOAC, 1995)에 따라 $2 \times 2 \mathrm{~cm}$ 의 $\mathrm{CFP}$ 필름 시료를 $105^{\circ} \mathrm{C}$ 에서 24 시간 처리하여 항량을 맞춘 다음, $20 \mathrm{~mL}$ 의 증류 수를 첨가해 24시간 shaking 한 뒤 다시 $105^{\circ} \mathrm{C}$ 에서 24 시간 처 리하여 측정하였다.

필름의 색도 측정. 필름의 색도 측정은 색차계(Minolta, CR-400, Japan)를 사용하였으며, 각 필름의 색도는 표준백판 $\left(L^{*}=97.52\right.$, $\left.a^{*}=-0.13, b^{*}=1.75\right)$ 을 기준으로 나타내었다.

Total color difference $(\Delta E)$ 는 다음과 같은 식을 이용하여 측정 하였고(Lee와 Rhim, 2000), 각 필름은 3번 반복하여 실험하였다.

$$
\Delta E=\left[\left(\Delta L^{*}\right)^{2}+\left(\Delta a^{*}\right)^{2}+\left(\Delta b^{*}\right)^{2}\right]^{1 / 2}
$$

또한, 필름의 불투명도(opacity)를 측정하기 위해, spectrophotometer 
(UV-2450, Shimadzu Corporation, Japan)를 이용하여 $660 \mathrm{~nm}$ 에 서 흡광도를 측정하였고, 필름의 두께 $(\mathrm{mm})$ 로 나누어 opacity(A $\mathrm{mm}^{-1}$ )를 측정하였다(Atef 등, 2014).

DPPH radical 소거능 측정. Wang 등(2013)의 방법에 따라 필 름 $50 \mathrm{mg}$ 에 $10 \mathrm{~mL}$ 의 증류수를 첨가하여 제조한 필름 용액 $9 \mathrm{~mL}$ 에 메탄올에 용해시킨 $1 \mathrm{mM}$ DPPH (2,2-diphenyl-1picrylhydrazyl) $3 \mathrm{~mL}$ 를 가하여 혼합 한 후, 암소에서 1시간 보 관한 뒤 $517 \mathrm{~nm}$ 에서 흡광도를 측정하였다. Blank는 $1 \mathrm{mM}$ $\mathrm{DPPH}$ 용액으로 하였으며, 각 필름 용액에 따른 $\mathrm{DPPH}$ radical 소거능은 DPPH radical scavenging activity $(\%)=\left(\mathrm{A}_{\text {blank }}-\mathrm{A}_{\text {sample }}\right) /$ $\mathrm{A}_{\text {sample }} \times 100$ 에 의하여 산출하였다.

균주 배양. Escherichia coli O157:H7 (KCTC 1682), Listeria monocytogenes (KCTC 13069), Staphylococuus aureus (KCTC 1621)를 tryptic soy broth (Difco Laboratories, USA)에 각각 접종하여 $37^{\circ} \mathrm{C}, 24$ 시간 배양 한 뒤 $2,000 \times g$ 에서 15 분간 원심 분리 하여 얻은 농축된 균을 사용하였다.

필름의 항균성 측정. E. coli O157:H7, L. monocytogenes, S. aureus (7-8 log CFU/g)를 MacConkey Sorbitol Agar (Difco Laboratories, USA), Oxford Medium (Difco Laboratories, USA), Mannitol Salt Agar (BBL Laboratories, USA) plate에 각각 $0.1 \mathrm{~mL}$ 씩 분주하여 도말 한 다음 직경이 $10 \mathrm{~mm}$ 이 되도록 자른 $\mathrm{CFP}$ 필름을 균이 접종된 배지에 부착 시켜 $4^{\circ} \mathrm{C}$ 에서 1 시간 동 안 방치시켰다. E. coli $\mathrm{O} 157: \mathrm{H} 7, S$. aureus 는 $37^{\circ} \mathrm{C}$ 에서 24시 간, L. monocytogenes는 $37^{\circ} \mathrm{C}$ 에서 48 시간 배양한 뒤, 필름의 항균성 물질에 의해 생성된 inhibition zone의 직경을 측정하였 으며, 한 시료 당 3반복으로 실험하였다(Lim 등, 2009).

통계 분석. 실험결과는 SAS프로그램 (Statistical Analysis System program version 8.2, SAS Institute Inc, USA)을 사용 하여 $p<0.05$ 수준에서 분산분석과 Duncan's multiple range test를 실시하였으며, 모든 실험 결과는 평균 \pm 표준편차로 나타 냈다.

\section{결과 및 고찰}

옥피 단백질의 추출 및 SDS-PAGE profile. 수용성, 알칼리, 등 전점, 유기용매 방법으로 추출된 단백질의 수율은 각각 $3.1,5.8$, $1.5,1.6 \%$ 로 알칼리 용액을 이용해 추출하는 방법의 수율이 가 장 좋았다. 또한, 추출된 단백질의 SDS-PAGE profile 결과(Fig. 1 ), 수용성 추출 단백질은 $10-15 \mathrm{kDa}$, 유기용매 추출 단백질은 $14,18,22 \mathrm{kDa}$, 등전점 추출 단백질과 알칼리 추출 단백질은 약 $28 \mathrm{kDa}$ band가 주요 단백질로 나타났다. Shukla와 Cheryan (2000)의 연구에 따르면 $\alpha$-zein은 $24,22 \mathrm{kDa}, \beta$-zein은 24,22 , $14 \mathrm{kDa}$ 이 주요 단백질이고, Ludevid 등(1984)은 corn glutelin이 $28,58 \mathrm{kDa}$ 이 주요 단백질 분자량으로, 본 연구에서의 수용성

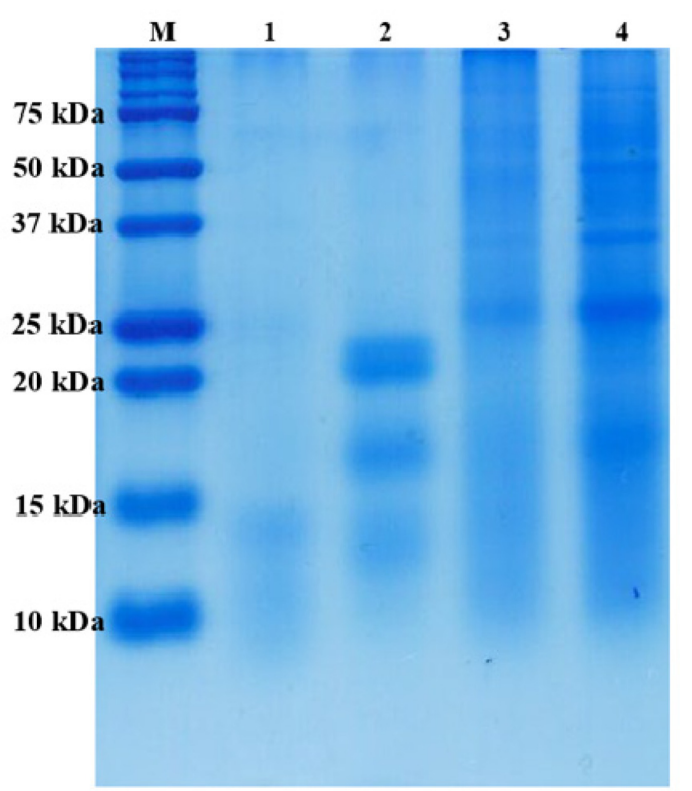

Fig. 1 SDS-PAGE profiles of CFP extracted using different methods. M: Molecular weight marker proteins, 1: water extraction, 2: organic solvent extraction, 3: isoelectric point precipitation 4: alkaline method.

추출법 이외의 방법에 의한 SDS-PAGE profile 결과와 유사하 다고 판단된다. 또한 기존 문헌과 다소 차이를 보이는 이유로 는, 본 연구에서 사용한 시료가 얻어지는 과정 중 sulfur dioxide, 고온 등에 노출됨에 따른 차이라고 판단된다. 따라서 본 연구에서는 추출 효율이 가장 높은 알칼리 방법을 이용하여 추출한 $\mathrm{CFP}$ 를 필름 제조에 사용하였다.

가소제, 가교제 종류에 따른 CFP 필름의 물성. 단백질 필름을 제조할 때 필름의 부스러짐을 줄여 주고 유연성을 향상시키기 위해 가소제를 첨가하는데(Cao 등, 2007), 본 연구에서는 가소 제로 $\mathrm{GLY}, \mathrm{SUC}, \mathrm{SOR}, \mathrm{FRU}$ 를 첨가하였다. 그 결과 $\mathrm{GLY}$ 를 첨가한 필름은 너무 끈적여 물성측정이 불가능 한 반면, $\mathrm{SUC}$ 를 첨가한 경우 $\mathrm{TS}$ 와 $\mathrm{E}$ 가 $5.64 \mathrm{MPa}, 5.83 \%, \mathrm{SOR}$ 를 첨가한 경우 $\mathrm{TS}$ 와 $\mathrm{E}$ 가 $1.15 \mathrm{Mpa}, 4.32 \%, \mathrm{FRU}$ 를 첨가한 경우 $\mathrm{TS}$ 와 E가 $2.25 \mathrm{MPa}, 18.74 \%$ 의 범위를 나타내었다. Song 등(2012)의 연구 보고에 따르면 일반적으로 분자량이 큰 가소제보다 작은 가소제의 혼합 능력이 더 좋아 필름의 유연성을 더 향상시켜 준다고 알려져 있기에, $\mathrm{FRU}$ 의 분자량이 작기 때문에 높은 $\mathrm{E}$ 를 가졌다고 판단된다.

Galietta 등(1998)은 가교제는 필름의 단백질 결합에 영향을 주어, 인장강도 등을 향상시킨다고 보고하였는데, 본 연구에서 는 ferulic acid, tannic acid, cinnamaldehyde를 FRU 함유 필

Table 1 Mechanical properties of the CFP films ( $5 \mathrm{~g}$ CFP, $2 \mathrm{~g}$ fructose) with different type of cross-linking agents

\begin{tabular}{ccccc}
\hline Cross-linking agent & Tensile strength $(\mathrm{MPa})$ & Elongation $(\%)$ & WVP $\left(\mathrm{ng} \mathrm{m} / \mathrm{m}^{2} \mathrm{sPa}\right)$ & Film solubility $(\%)$ \\
\hline Control & $2.25 \pm 0.09^{\mathrm{b}}$ & $18.74 \pm 3.07^{\mathrm{a}}$ & $4.28 \pm 0.70^{\mathrm{a}}$ & $45.37 \pm 0.75^{\mathrm{ab}}$ \\
Tannic acid & $5.77 \pm 0.19^{\mathrm{a}}$ & $4.17 \pm 0.10^{\mathrm{b}}$ & $2.82 \pm 0.14^{\mathrm{b}}$ & $49.85 \pm 3.02^{\mathrm{a}}$ \\
Ferulic acid & $5.48 \pm 1.03^{\mathrm{a}}$ & $5.98 \pm 1.90^{\mathrm{b}}$ & $2.69 \pm 0.27^{\mathrm{b}}$ & $43.71 \pm 3.14^{\mathrm{bc}}$ \\
Cinnamaldehyde & $6.44 \pm 1.14^{\mathrm{a}}$ & $4.07 \pm 0.35^{\mathrm{b}}$ & $2.47 \pm 0.31^{\mathrm{b}}$ & $40.25 \pm 1.78^{\mathrm{c}}$ \\
\hline
\end{tabular}

Means \pm SD.

${ }^{\mathrm{a}-\mathrm{c}}$ Values in a column followed by different superscript letters are significantly different $(p<0.05)$. 
Table 2 Mechanical properties of the CFP films ( $5 \mathrm{~g}$ CFP, $2 \mathrm{~g}$ fructose) with different amounts of cinnamaldehyde

\begin{tabular}{|c|c|c|c|c|}
\hline Cinnamaldehyde (\%) & Tensile strength (MPa) & Elongation (\%) & WVP (ng m/m² sPa) & Film solubility (\%) \\
\hline 0 & $2.25 \pm 0.09^{\mathrm{c}}$ & $18.74 \pm 3.07^{\mathrm{a}}$ & $4.28 \pm 0.70^{\mathrm{a}}$ & $45.37 \pm 0.75^{\mathrm{a}}$ \\
\hline 0.01 & $7.51 \pm 0.83^{\mathrm{ab}}$ & $8.90 \pm 0.42^{b}$ & $2.89 \pm 0.16^{\mathrm{b}}$ & $45.22 \pm 2.05^{\mathrm{a}}$ \\
\hline 0.03 & $8.97 \pm 0.87^{\mathrm{a}}$ & $8.87 \pm 0.09^{b}$ & $2.79 \pm 0.11^{\mathrm{b}}$ & $40.69 \pm 0.60^{b}$ \\
\hline 0.05 & $6.44 \pm 1.14^{\mathrm{b}}$ & $4.07 \pm 0.35^{\mathrm{c}}$ & $2.47 \pm 0.31^{\mathrm{b}}$ & $40.25 \pm 1.78^{b}$ \\
\hline
\end{tabular}

Means \pm SD.

${ }^{\mathrm{a}-\mathrm{c}}$ Values in a column followed by different superscript letters are significantly different $(p<0.05)$.

Table 3 Optical properties of the CFP films ( $5 \mathrm{~g}$ CFP, $2 \mathrm{~g}$ fructose) with different amounts of cinnamaldehyde

\begin{tabular}{|c|c|c|c|c|c|}
\hline Cinnamaldehyde (\%) & $L^{*}$ & $a^{*}$ & $b^{*}$ & $\Delta \mathrm{E}$ & Opacity $\left(\mathrm{A} \mathrm{mm^{-1 } )}\right.$ \\
\hline 0 & $84.06 \pm 0.67^{\mathrm{a}}$ & $-3.66 \pm 0.28^{a}$ & $43.14 \pm 0.95^{\mathrm{a}}$ & - & $8.73 \pm 0.98^{\mathrm{a}}$ \\
\hline 0.01 & $83.83 \pm 0.31^{\mathrm{a}}$ & $-3.43 \pm 0.10^{\mathrm{a}}$ & $46.05 \pm 0.15^{\mathrm{a}}$ & $2.07 \pm 0.21^{\mathrm{a}}$ & $8.06 \pm 0.42^{\mathrm{a}}$ \\
\hline 0.03 & $84.35 \pm 2.11^{\mathrm{a}}$ & $-3.47 \pm 0.54^{\mathrm{a}}$ & $44.62 \pm 3.65^{\mathrm{a}}$ & $2.11 \pm 0.62^{\mathrm{a}}$ & $7.81 \pm 0.28^{a}$ \\
\hline 0.05 & $83.77 \pm 0.30^{\mathrm{a}}$ & $-3.50 \pm 0.04^{\mathrm{a}}$ & $46.88 \pm 0.24^{\mathrm{a}}$ & $2.81 \pm 0.16^{\mathrm{a}}$ & $7.84 \pm 0.25^{\mathrm{a}}$ \\
\hline
\end{tabular}

Means \pm SD.

${ }^{a}$ Values in a column followed by different superscript letters are significantly different $(p<0.05)$.

름에 첨가하여 인장강도 향상 능력을 비교하였다(Table 1). 각 가교제를 $0.05 \%$ 씩 첨가한 결과, $\mathrm{TS}$ 는 증가하였고 $\mathrm{E}$ 값은 감소 하였는데, 이는 가교제가 단백질 간의 결합을 증가시키기 때문 이라고 판단된다 $(\mathrm{Ku}$ 등, 2007). Ferulic acid, tannic acid, cinnamaldehyde를 첨가한 필름의 $\mathrm{TS}$ 가 각각 $5.77,5.48,6.44$ $\mathrm{MPa}, \mathrm{E}$ 가 $4.17,5.98,4.07 \%$ 로 세 가교제 중 cinnamaldehyde 가 가장 좋은 $\mathrm{TS}$ 향상 능력을 보였다.

$\mathrm{WVP}$ 의 경우, control에 비해 WVP가 감소하는 경향을 보였 는데, 이는 가교제에 의한 단백질 간의 결합 증가로 인하여 수 분이 침투할 수 있는 부분이 줄어들어 그 값이 감소하였다고 판단된다(Wu 등, 2013). 그리고 film solubility의 경우, tannic acid를 첨가한 필름은 $49.85 \%$ 로 control보다 높은 반면에, ferulic acid와 cinnamaldehyde는 43.71, 40.25\%로 control보다 낮은 값을 보였다. 이러한 차이는 $\mathrm{CFP}$ 와 가교제 간의 결합 차 이에서 기인한 것이라고 판단된다(Cao 등, 2007).

가교제 비율에 따른 CFP 필름의 물리적, 광학적 특성. 가소제 로 $\mathrm{FRU}$ 를 첨가한 $\mathrm{CFP}$ 필름의 $\mathrm{TS}$ 를 개선시키기 위해 선택된 가교제인 cinnamaldehyde를 $0.01,0.03,0.05 \%$ 첨가하여 단백 질 필름을 제조하였다(Table 2). Cinnamaldehyde를 $0.01 \%$ 첨가 하였을 때 $\mathrm{TS}$ 와 $\mathrm{E}$ 는 $7.51 \mathrm{MPa}$ 와 $8.90,0.03 \%$ 첨가하였을 때 $8.97 \mathrm{MPa}$ 와 $8.87,0.05 \%$ 첨가하였을 때 $6.44 \mathrm{MPa}$ 와 $4.07 \%$ 로 대조구에 비해 $\mathrm{TS}$ 는 증가하다가 감소하였고 $\mathrm{E}$ 는 $\mathrm{TS}$ 와는 반대 로 감소하였는데, 일반적으로 필름의 $\mathrm{TS}$ 가 증가하면 $\mathrm{E}$ 는 $\mathrm{TS}$ 와 반비례하게 감소하는 경향을 보인다(Song 등, 2012). 본 연구에 서는 전반적으로 cinnamaldehyde를 $0.03 \%$ 첨가하였을 때 물성 개선 측면에서 가장 효과적이었다. Ojagh 등(2010)은 chitosan film에 $2 \%$ 의 cinnamon oil의 첨가 시, 물성이 대조구와 비교하 였을 때 $\mathrm{TS}$ 가 $18.26 \mathrm{MPa}$ 증가하였고 $\mathrm{E}$ 는 $21.15 \%$ 감소하였다 고 보고하였고, $\mathrm{Ku}$ 등(2007)은 Gelidium corneum film에 $0.01 \%$ cinnamaldehyde를 첨가 시, $\mathrm{TS}$ 가 $8.3 \mathrm{MPa}$ 증가하였고 $\mathrm{E}$ 는 $3.7 \%$ 감소했다고 보고하였는데, 이러한 연구 보고는 본 연 구 결과와 유사함을 나타낸다.

$\mathrm{WVP}$ 의 경우, cinnamaldehyde 비율이 증가할수록 감소하는 경향을 보였는데, Rojas-Grä 등(2006)의 연구에 따르면 WVP 는 일반적으로 필름의 친수성 부분과 소수성 부분의 비율에 영
향을 받는데, apple puree film에 소수성인 cinnamaldehyde를 주로 함유한 cinnamon oil을 첨가하였을 때 WVP 값이 감소하 였다고 보고하여 본 연구 결과와 유사하였다. WS 또한 대조구 와 비교하여 cinnamaldehyde를 첨가하였을 때 소수성 증가에 따른 물에 대한 용해도 감소에 의해 값이 감소하는 경향을 보 였는데, Ojagh 등(2010)의 연구에서도 cinnamon oil의 비율이 증가할수록 film solubility 값이 대조구에 비해 감소하였다.

Cinnamaldehyde를 첨가한 CFP 필름의 광학적 특성을 Table 3에 나타내었다. 본 연구에서 대조구 필름과 cinnamaldehyde를 첨가한 필름의 색도를 비교한 결과, 대조구 필름의 경우 $L$ *값 은 $84.06, a$ *값은 $-3.66, b$ *값은 43.14이며, cinnamaldehyde를 첨가한 필름의 경우 $L^{*}$ 값은 $83.98, a^{*}$ 값은 $-3.47, b^{*}$ 값은 45.85로 유의적인 차이는 없었다. 그리고 $\mathrm{FRU}$ 만을 첨가한 필름 을 대조구로 하여 cinnamaldehyde를 첨가 하였을 때의 전체적 인 색 차이를 $\Delta E$ 로 나타내었는데, cinnamaldehyde 첨가 양에 따른 유의적인 차이는 없었다. Opacity 값 또한, 대조구 필름과 cinnamaldehyde를 첨가한 필름 간의 유의적인 차이가 없었는데, 이는 cinnamaldehyde가 투명한 액체 성상을 띠기 때문이라고 판단된다. 따라서 본 연구 결과, $\mathrm{CFP}$ 필름의 모든 물성을 고려 했을 때, 가소제로 $2 \mathrm{~g}$ FRU, 가교제로 $0.03 \%$ cinnamaldehyde 첨가할 때 가장 최적의 물성을 갖는 필름을 제조할 수 있다고 판단된다.

GTE 함유 CFP 필름의 물리적, 광학적 특성. 필름의 최적조건 인 $5 \% \mathrm{CFP}, 40 \% \mathrm{FRU}, 0.03 \%$ cinnamaldehyde 필름에 다양 한 농도의 GTE를 첨가하여 필름을 제조하였다(Table 4). GTE 첨가 양에 따른 $\mathrm{CFP}$ 필름은 대조구 필름에 비해 $\mathrm{TS}$ 는 $0.5 \%$ 일 때 $9.01 \mathrm{MPa}, 1.0 \%$ 일 때 $11.21 \mathrm{MPa}, 1.5 \%$ 일 때 $5.15 \mathrm{MPa}$ 로 증가하다 감소하는 경향을 보였고, $\mathrm{E}$ 는 $7.78,7.57,3.69 \%$ 로 GTE 첨가 양이 증가함에 따라 감소하는 경향을 보였다. GTE 의 폴리페놀 성분이 $\mathrm{CFP}$ 와 수소결합, 소수성 결합에 의해 $\mathrm{TS}$ 가 증가하였는데(Wang 등, 2013), Hong 등(2009)의 연구에서도 Gelidium corneum film에 GTE를 $0.5,1.4,2.8,4.2 \%$ 로 첨가 함에 따라 $\mathrm{TS}$ 는 증가하였고 $\mathrm{E}$ 는 감소하였다는 결과는 본 연구 결과와 유사하다. 그러나 GTE를 $1.5 \%$ 첨가하였을 때 TS가 급 격히 감소하였는데, 이는 $\mathrm{CFP}$ 와 결합하지 않은 GTE 폴리페놀 
Table 4 Mechanical properties of the CFP films ( $5 \mathrm{~g}$ CFP, $2 \mathrm{~g}$ Fructose, $0.03 \%$ cinnamaldehyde) with different amounts of GTE

\begin{tabular}{|c|c|c|c|c|}
\hline Green tea extract $(\%)$ & Tensile strength (MPa) & Elongation (\%) & WVP (ng m/m² sPa) & Film solubility (\%) \\
\hline 0 & $8.97 \pm 0.87^{b}$ & $8.87 \pm 0.09^{\mathrm{a}}$ & $2.79 \pm 0.11^{\mathrm{a}}$ & $40.69 \pm 0.60^{c}$ \\
\hline 0.5 & $9.01 \pm 1.55^{\mathrm{b}}$ & $7.78 \pm 0.13^{b}$ & $2.14 \pm 0.05^{\mathrm{c}}$ & $51.49 \pm 2.92^{b}$ \\
\hline 1.0 & $11.21 \pm 0.98^{\mathrm{a}}$ & $7.57 \pm 0.22^{b}$ & $2.09 \pm 0.07^{\mathrm{c}}$ & $56.48 \pm 0.82^{\mathrm{a}}$ \\
\hline 1.5 & $5.15 \pm 0.17^{\mathrm{c}}$ & $3.69 \pm 0.68^{\mathrm{c}}$ & $2.55 \pm 0.09^{b}$ & $58.41 \pm 0.95^{\mathrm{a}}$ \\
\hline
\end{tabular}

Means \pm SD.

${ }^{\mathrm{a}-\mathrm{c}}$ Values in a column followed by different superscript letters are significantly different $(p<0.05)$.

Table 5 Optical properties of the CFP films (5 g CFP, 2 g Fructose, $0.03 \%$ cinnamaldehyde) with different amounts of GTE

\begin{tabular}{|c|c|c|c|c|c|}
\hline Green tea extract $(\%)$ & $L^{*}$ & $a^{*}$ & $b^{*}$ & $\Delta \mathrm{E}$ & Opacity $\left(\mathrm{A} \mathrm{mm}^{-1}\right)$ \\
\hline 0 & $84.35 \pm 2.11^{\mathrm{a}}$ & $-3.47 \pm 0.54^{\mathrm{d}}$ & $44.62 \pm 3.65^{\mathrm{c}}$ & - & $7.81 \pm 0.28^{\mathrm{d}}$ \\
\hline 0.5 & $79.57 \pm 0.11^{\mathrm{b}}$ & $-2.69 \pm 0.08^{c}$ & $56.56 \pm 0.62^{b}$ & $12.88 \pm 0.51^{\mathrm{c}}$ & $13.77 \pm 0.23^{\mathrm{c}}$ \\
\hline 1.0 & $73.55 \pm 0.55^{\mathrm{c}}$ & $-0.54 \pm 0.22^{\mathrm{b}}$ & $60.06 \pm 0.59^{\mathrm{b}}$ & $19.08 \pm 0.36^{\mathrm{b}}$ & $17.29 \pm 0.43^{b}$ \\
\hline 1.5 & $69.23 \pm 0.28^{\mathrm{d}}$ & $1.24 \pm 0.13^{\mathrm{a}}$ & $64.17 \pm 0.08^{\mathrm{a}}$ & $25.08 \pm 0.12^{\mathrm{a}}$ & $20.90 \pm 1.26^{\mathrm{a}}$ \\
\hline
\end{tabular}

Means \pm SD.

${ }^{\text {a-d }}$ Values in a column followed by different superscript letters are significantly different $(p<0.05)$.

수산기 간 결합에 의한 것이라고 판단되는데(Bandyopadhyay 등, 2012), Mathew와 Abraham(2008) 또한 starch-chitosan film에 가교제로 ferulic acid를 첨가 시 $75 \mathrm{mg}$ 까지 $\mathrm{TS}$ 가 증가하였다가 $100 \mathrm{mg}$ 첨가한 경우 $\mathrm{TS}$ 가 감소하는 결과를 가졌다고 보고한 바 있다.

WVP는 GTE $1.0 \%$ 까지 첨가하였을 때 그 값이 $2.09 \mathrm{ng} \mathrm{m} /$ $\mathrm{m}^{2} \mathrm{sPa}$ 로 대조구 필름의 WVP 값인 $2.79 \mathrm{ng} \mathrm{m} / \mathrm{m}^{2} \mathrm{sPa}$ 에 비해 감소하였다. 이는 GTE의 폴리페놀 성분과 $\mathrm{CFP}$ 사이의 수소결 합 및 소수성 결합이 증가함에 따라 수분이 침투할 수 있는 부 분이 줄어들어 감소하였으나, GTE를 $1.5 \%$ 첨가하였을 때는 폴 리페놀 성분과 $\mathrm{CFP}$ 사이의 결합력이 오히려 감소하여 그 값이 증가하였다. 이러한 결과와 유사하게 $\mathrm{Wu}$ 등(2013)은 silver carp skin gelatin film에 GTE를 0.3 과 $0.7 \%$ 첨가하였을 때 대조구 필름에 비해 WVP가 감소하였다고 보고하였다. WS는 GTE 첨 가 양이 증가할수록 그 값이 증가하는 경향을 보였는데, GTE 에 존재하는 폴리페놀의 수산기의 증가로 cinnamaldehyde만 첨 가했을 때 보다 친수성에 가까워져서 대조구 필름에 비해 수분 과 더 많은 수소결합을 하기 때문이라고 판단되며(Nouri와 Mohammadi Nafchi, 2014), Giménez 등(2013)의 연구 에서도 agar/gelatin film에 GTE를 첨가 하였을 때 WS가 증가하였다. $\mathrm{GTE}$ 를 첨가한 $\mathrm{CFP}$ 필름의 광학적 특성을 Table 5에 나타내었 다. 대조구 필름과 달리 GTE 첨가 양이 증가 할수록 필름의 $L^{*}$ 값은 감소하였고, $a^{*}$ 값과 $b^{*}$ 값은 증가하였다. 이는 필름 제조 과정 중 가소제로 첨가된 fructose와 카테킨이 반응하여 당화된 카테킨이 형성되었기 때문이며, Dicastillo 등(2011)의 연구에서 도 $\mathrm{EVOH}$ film에 GTE를 첨가했을 때 이와 유사한 결과를 나 타내었다. $\Delta E$ 값 또한 대조구 필름과 비교하였을 때 GTE 첨가 양에 비례하여 증가하였다.

GTE를 첨가한 필름의 opacity 결과, 대조구 필름에 비해 GTE 첨가 양이 증가 할수록 불투명도가 증가하는 경향을 보였 는데, $\mathrm{Wu}$ 등(2013)의 gelatin film에 GTE를 첨가하였을 때 opacity가 증가한 보고와 일치하였다. 이러한 결과는 GTE를 첨 가하였을 때 빛에 의한 산화에 대한 보호기능이 강화되어 포장 된 식품의 저장성을 높일 수 있다고 판단된다(Wu 등, 2013).

GTE 함유 CFP 필름의 항산화 및 항균활성. GTE를 첨가한

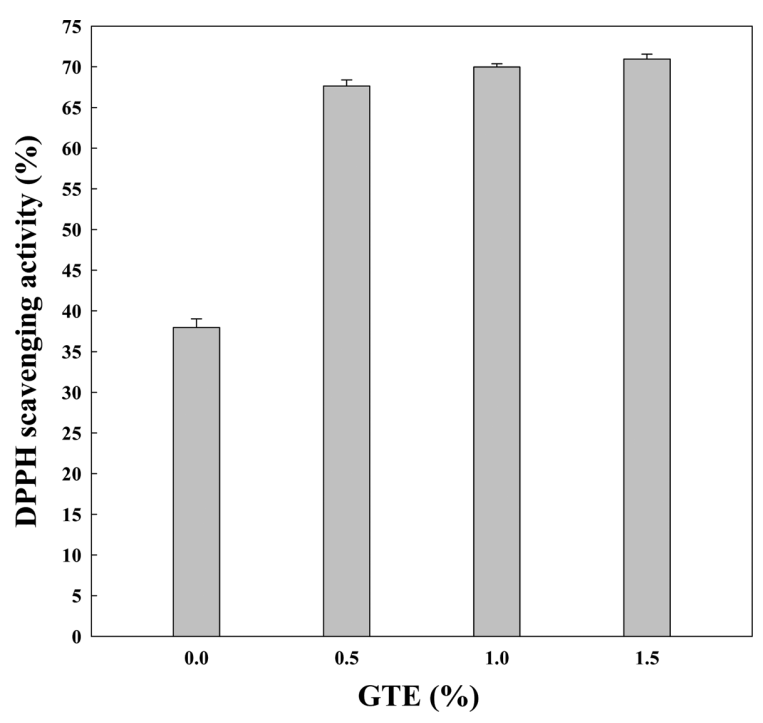

Fig. 2 DPPH radical scavenging activity of the CFP films with various amounts of GTE.

$\mathrm{CFP}$ 필름의 $\mathrm{DPPH}$ radical 소거능 결과, GTE 첨가 양이 증가 할수록 DPPH radical 소거능이 비례하게 증가하였다(Fig. 2). 이 는 GTE에 존재하는 폴리페놀의 수산기가 DPPH radical과 반 응되었기 때문이라고 판단되는데, Wang 등(2013)의 연구에서도 chitosan film에 tea polyphenol을 첨가하였을 때 이와 유사한 결과를 보였으며, 이러한 결과는 식품 포장에 적용하였을 때 지 방산화를 저해하여 저장성을 높일 수 있음을 나타낸다. 본 연 구에서 GTE를 첨가하지 않은 film에서도 DPPH radical 소거능 이 측정되었는데, 이는 가교제로 첨가한 cinnamaldehyde가 항 산화능을 가지고 있기 때문이라고 판단된다. Mathew와 Abraham (2006)의 연구에서도 cinnamaldehyde가 주요 성분인 cinnamon bark extract의 ABTS radical 소거능을 측정한 결과, $0.625 \%$ 의 경우 소거능이 약 $80 \%$ 로 항산화능이 있음을 보고한 바 있다.

GTE를 첨가한 $\mathrm{CFP}$ 필름의 E. coli $\mathrm{O} 157: \mathrm{H} 7$, L. monocytogenes, $S$ a areus 에 대한 항균활성 결과, GTE 첨가 양이 증가할수록 


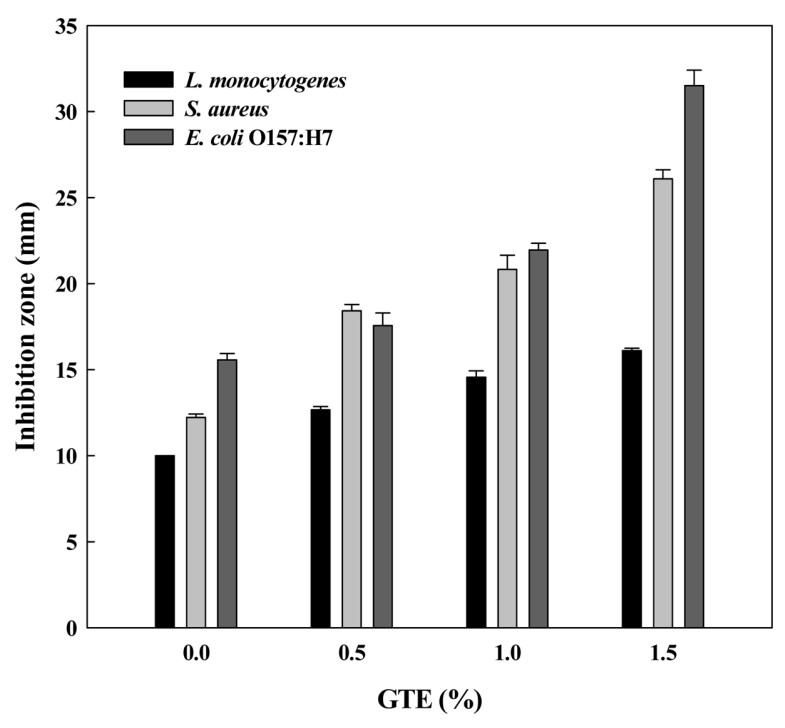

Fig. 3 Inhibition zone of the CFP films with various amounts of GTE.

미생물의 생장을 억제하는 능력이 비례하게 증가하는 것을 확 인할 수 있었다(Fig. 3). 이는 GTE의 폴리페놀 성분이 미생물 의 DNA, RNA 대사에 영향을 끼치며 세포분열을 방해하기 때 문에 미생물의 생장이 억제된다고 판단된다(Kumudavally 등, 2008). Kim 등(2006)의 연구에서도 soy protein isolate film에 GTE를 첨가하여 항균성 실험을 한 결과, GTE 함량이 증가할 수록 Streptococcus mutans와 Staphylococcus aureus의 생장 억 제 능력이 증가하여 본 연구와 유사한 결과를 보였다. 또한, $L$. monocytogenes 보다는 E. coli $\mathrm{O} 157: \mathrm{H} 7$ 와 S. aureus 에 대해 항균활성이 더 좋았으며, S. aureus 보다는 E. coli $\mathrm{O} 157: \mathrm{H} 7$ 에 더 효과적임을 알 수 있었다.

따라서 본 연구 결과, $\mathrm{GTE}$ 를 첨가한 $\mathrm{CFP}$ 필름의 모든 물성 과 항산화, 항균활성을 고려했을 때, 가소제로 $2 \mathrm{~g} \mathrm{FRU,} \mathrm{가교}$ 제로 $0.03 \%$ cinnamaldehyde, 항균, 항산화 물질로 $1.0 \%$ GTE 를 첨가할 때 필름의 최적 제조 조건으로 판단된다.

\section{초 록}

옥수수의 습식 분쇄 공정 중 나오는 부산물인 옥피로부터 옥피 단백질 $(\mathrm{CFP})$ 을 추출하였다. 다양한 가소제와 가교제를 첨가하 여 $\mathrm{CFP}$ 필름을 제조한 후, 필름의 물성을 측정하였다. 본 연구 에서 사용된 가소제와 가교제 중, $2 \mathrm{~g}$ fructose와 $0.03 \%$ cinnamaldehyde를 첨가한 필름이 가장 좋은 물성을 가졌다. 또 한 여러 농도 $(0,0.5,1.0,1.5 \%)$ 의 녹차 추출물 $(\mathrm{GTE})$ 을 첨가한 $\mathrm{CFP}$ 필름을 제조하였다. $\mathrm{GTE}$ 의 농도가 증가함에 따라 $\mathrm{CFP}$ 필 름의 인장강도, 수분 용해도, 불투명도는 증가하였고, 반면에 신 장률과 필름의 수분투과도는 대조구에 비해 감소하였다. GTE 첨가한 $\mathrm{CFP}$ 필름의 항산화성은 $\mathrm{DPPH}$ 소거능으로 측정하였는 데, GTE 농도가 증가함에 따라 증가하였다. 그리고 E. coli O157:H7, L. monocytogenes, S. aureus 에 대한 항균성 실험을 한 결과 또한 GTE 농도가 증가함에 따라 증가하였다. 따라서 본 연구 결과, GTE 첨가는 $\mathrm{CFP}$ 필름의 항산화, 항균효과를 가 져다 준다고 판단된다.
Keywords 녹차추출물 - 단백질 필름 - 옥피 · 항균

\section{References}

AOAC (1995) Official method of analysis. Association of Official Analytical Chemists (NO. 993.13), USA.

ASTM (1983) Standard test method for water vapor transmission of material. E 96-80, Annual Book of ASTM Standard, USA.

ASTM (1993) Standard test method for tensile properties of plastics. D638M, Annual Book of ASTM Standard, USA.

Atef M, Rezaei M, and Behrooz R (2014) Preparation and characterization agar-based nanocomposite film reinforced by nanocrystalline cellulose. Int J Biol Macromol 70, 537-44.

Bandyopadhyay P, Ghosh AK, and Ghosh C (2012) Recent developments on polyphenol-protein interactions: effects on tea and coffee taste, antioxidant properties and the digestive system. Food Funct 3, 592-605.

Cao N, Fu Y, and He J (2007) Mechanical properties of gelatin films crosslinked, respectively, by ferulic acid and tannin acid. Food Hydrocolloid 21, 575-84.

Chiu PE and Lai LS (2010) Antimicrobial activities of tapioca starch/ decolorized hsian-tsao leaf gum coatings containing green tea extracts in fruit-based salads, romaine hearts and pork slices. Int J Food Microbiol 139, 23-30.

Galietta G, Di Gioia L, Guilbert S, and Cuq B (1998) Mechanical and thermomechanical properties of films based on whey proteins as affected by plasticizer and crosslinking agents. J Dairy Sci 81, 3123-30.

Gáspár M, Kálmán G, and Réczey K (2007) Corn fiber as a raw material for hemicellulose and ethanol production. Process Biochem 42, 1135-9.

Giménez B, López de Lacey A, Pérez-Santín E, López-Caballero ME, and Montero P (2013) Release of active compounds from agar and agargelatin films with green tea extract. Food Hydrocolloid 30, 264-71.

Hong YH, Lim GO, and Song KB (2009) Physical properties of Gelidium corneum-gelatin blend films containing grapefruit seed extract or green tea extract and its application in the packaging of pork loins. J Food Sci 74, C6-10.

Kim KM, Lee BY, Kim YT, Choi SG, Lee J, Cho SY et al. (2006) Development of antimicrobial edible film incorporated with green tea extract. Food Sci Biotechnol 15, 478-81.

$\mathrm{Ku}$ K, Seo Y, and Song KB (2007) Physical properties of Gelidium corneum films treated with cinnamaldehyde. J Food Sci Nutr 12, 122-5.

Kumudavally KV, Phanindrakumar HS, Tabassum A, Radhakrishna K, and Bawa AS (2008) Green tea-A potential preservative for extending the shelf life of fresh mutton at ambient temperature $\left(25 \pm 2^{\circ} \mathrm{C}\right)$. Food Chem 107, 426-33.

Laemlli UK (1970) Cleavage of structural proteins during the assembly of the head of bacteriophage T4. Nature 227, 680-5.

Lee JH, Song NB, Jo WS, and Song KB (2014) Effects of nanoclay type and content on the physical properties of sesame seed meal protein composite films. Int J Food Sci Technol 49, 1869-75.

Lee JJ and Rhim JW (2000) Characteristics of edible films based with various cultivars of sweet potato starch. Korean J Food Sci Technol 32, 834-42.

Lee MS, Lee SH, Park SK, Bae DH, Ha SD, and Song KB (2004) Change in quality of Pine Nuts (Pinus koraiensis) and Walnuts (Juglans regia) coated with protein film containing green tea extract during storage. Korean J Food Sci Technol 36, 842-6.

Lim GO, Hong YH, and Song KB (2009) Effect of various plasticizers and ferulic acid on the physical properties of Gelidium corneum film. $J$ Korean Soc Food Sci Nutr 38, 727-31.

Lim GO, Jang SA, Kim JY, Kim HJ, and Song KB (2010) Use of a gelatin film containing grapefruit seed extract in the packaging of strawberries. Korean J Food Preserv 17, 196-201.

Ludevid MD, Torrent M, Martinez-Izquierdo JA, Puigdomenech P, and Palau $\mathrm{J}$ (1984) Subcellular localization of glutelin-2 in maize (Zea mays L.) endosperm. Plant Mol Biol 3, 227-34.

Mathew S and Abraham TE (2006) Studies on the antioxidant activities of cinnamon (Cinnamomum verum) bark extracts, through various in vitro 
models. Food Chem 94, 520-8.

Mathew S and Abraham TE (2008) Characterisation of ferulic acid incorporated starch-chitosan blend films. Food Hydrocolloid 22, 826-35.

Nouri L and Mohammadi Nafchi A (2014) Antibacterial, mechanical, and barrier properties of sago starch film incorporated with betel leaves extract. Int J Biol Macromol 66, 254-9.

Ojagh SM, Rezaei M, Razavi SH, and Hosseini SMH (2010) Development and evaluation of a novel biodegradable film made from chitosan and cinnamon essential oil with low affinity toward water. Food Chem $\mathbf{1 2 2}$, 161-6.

Rojas-Graü MA, Avena-Bustillos RJ, Friedman M, Henika PR, MartínBelloso O, and McHugh TH (2006) Mechanical, barrier, and antimicrobial properties of apple puree edible films containing plant essential oils. J Agric Food Chem 54, 9262-7.

Rose DJ, Inglett GE, and Liu SX (2010) Utilisation of corn (Zea mays) bran and corn fiber in the production of food components. $J$ Sci Food Agric 90, 915-24.

Shin YJ, Jang SA, and Song KB (2011) Preparation and mechanical properties of rice bran protein composite films containing gelatin or red algae. Food Sci Biotechnol 20, 703-7.

Shin YJ, Song HY, Jo WS, Lee MJ, and Song KB (2013) Physical properties of a barley protein/nanoclay composite film containing grapefruit seed extract and antimicrobial benefits for packaging of Agaricus bisporus. Int J Food Sci Technol 48, 1736-43.

Shukla R and Cheryan M (2001) Zein: the industrial protein from corn. Ind Crops Prod 13, 171-92.

Song HY, Jo WS, Song NB, and Song KB (2012). Preparation of defatted grape seed meal protein composite films. J Korean Soc Food Sci Nutr 41, 1274-80.

Song NB, Song HY, Jo WS, and Song KB (2013) Physical properties of a composite film containing sunflower seed meal protein and its application in packaging smoked duck meat. J Food Eng 116, 789-95.

Wang B, Cheng B, and Feng H (2008) Enriched arabinoxylan in corn fiber for value-added products. Biotechnol Lett 30, 275-9.

Wang L, Dong Y, Men H, Tong J, and Zhou J (2013) Preparation and characterization of active films based on chitosan incorporated tea polyphenols. Food hydrocolloid 32, 35-41.

Wu J, Chen S, Ge S, Miao J, Li J, and Zhang Q (2013) Preparation, properties and antioxidant activity of an active film from silver carp (Hypophthalmichthys molitrix) skin gelatin incorporated with green tea extract. Food Hydrocolloid 32, 42-51. 